\title{
Covid-19 Memes: Hyperdemocracy Representation (Semiotic Study)
}

\author{
Prapti Wigati Purwaningrum ${ }^{1, *}$ Aceng Ruhendi Saifullah ${ }^{1}$ Dadang Sudana $^{1}$ \\ ${ }^{1}$ Linguistic Study Program, School of Postgraduate, Universitas Pendidikan Indonesia, Bandung, Indonesia \\ "Corresponding author. Email: tiwinurulhuda84@gmail.com
}

\begin{abstract}
A year has passed since the covid 19 pandemic started, and the government policy in terms of handling this pandemic has still been a controversial debate. There are allegations that the pandemic does not exist or is just a conspiracy; the government is considered to be confused when deciding on handling the pandemic, whether to impose a lockdown or to allow business investment activities to continue, and in terms of education, the government's measures are unable to determine the right system for distance learning. Some of the issues over the information were widely constructed through memes circulating on social media Instagram. This research is a case study that uses memes and netizen responses as research data. To understand the signs, meanings, and responses of netizens, the writer uses Peirce's semiotic, multimodal theory, and Welch's hyperdemocracy symptoms. Freedom of expression, giving opinions, making and spreading the information is based on individual justification. Nowadays, social media is able to influence, change netizens' way of thinking so that the discussion in the comment section leads to ridicule, criticize, and blame each other. In addition, it is also found that social media dominates the internet, this can be seen in some responses which support meme uploads on social media instagram. Through some of these indicators, there is an assumption that the phenomenon of hyperdemocracy in virtual space has emerged. Ultimately, the findings of this analysis will describe how the hyperdemocracy phenomenon began to appear in virtual space.
\end{abstract}

\section{Keywords: signs, meanings, hyperdemocracy, social media instagram, and covid 19 memes}

\section{INTRODUCTION}

Various information links, pictures, videos, and photos flood social media such as facebook, twitter, and instagram every time in our lives today. It is now easy for public to obtain various information needed, however; such information is frequently draining energy. The abundant information makes it more difficult for the public to choose credible sources of information. The information technology revolution led to the birth of various instant messaging apps, social media, and other platforms. New media is a type of media that gives public the opportunity to construct information or make news, spread it without any supervision and restrictions. According to [1] new media has several characteristics such as interconnectedness, the access includes individuals and public either as news makers or news receivers, open interaction, and accessible anywhere and anytime. All of those characteristics influence the emergence of new public spaces that allows anyone to participate without being limited by space and time.

Today, what is currently happening in society is that social media seems to be the only reference in exchanging and digging for information. Thus, social media becomes one of the causes of information overload, making it as evidence of an individual's freedom to express their opinions and it is considered as public voice and public movement. Each account owner presents information that he/she considers right, so it leads to a debate which may cause disunity in society. According to Ismail Fahmi quoted in (Kompas, 2021) that "not everything on social media represents public expression". Therefore, each individual must be very selective when choosing information in order not to be deceived by false information or hoaxes.

False information or hoaxes flooding social media are widely uploaded by anonymous accounts, making it difficult to prove the truth. Similar researches on the use of anonymous accounts on social media in uploading information, see [2], [3], [4], and [5]. On social media, the use of emoji plays a fairly important role because it can create a pleasant interaction so that information or messages do not seem too serious, besides; it can also be used in place of negative connotations and strengthen relationships between responders who do not meet each other face-to-face. [6], [7], [8], [9], and [10].

Constructing and responding to information done by netizens on social media is inseparable from 
language use. For instance, the memes uploaded on social media instagram are used to construct information that the creator believes as a thought and truth of a particular issue. Freedom of expression makes the development of democracy become increasingly rapid in virtual space. The meme was first introduced by[11] as a unit of cultural dissemination, ideas, such as songs, hairstyles, and fashion styles. As it is becoming more common today, there are many satirical memes showing a combination of sarcasm and irony through humor. Memes are spreading and growing very quickly in the digital world as a form of internet-based humor [12]; [13]. The spread of memes is very massive on social media, especially facebook, twitter, and instagram, all the three platforms have supporting features to upload memes and can be directly responded by netizens.

As the internet and technology are becoming more advanced, public space provides a wider place to engage in discussions, debates, self-expressions, and even severe criticism in virtual space. Freedom is conveyed through various signs, dictions, and images, all in the name of democracy. What is currently happening today is that social media is the only source of information. Every individual is free to create, spread the information based on what he/she believes. Similarly, netizens are free to respond and distrust the information found on social media. This condition is getting out of control with the increasing number of speeches made by netizens which insult, slander, threaten those who disagree with netizens. In the context of this study, the information constructed through memes receive various responses which tend to be anarchic. The responses supporting information in memes refer to an arrangement on what is featured in memes by using some harsh words and rude emojis aimed at the trending issue. Similarly, the responses denying information in memes include rude propositions and emojis directed at meme creators and other responders. These responses are based on individual justification so every responder feels that their reponses are the right ones.

As it has been stated above, it appears that through individual thoughts constructed in memes and disseminated on social media is able to influence and lead to intense debate. At first glance, the guarantee of freedom in public space for each individual is becoming real, but when democracy is determined by a large number of mass rather than the truth and the abundance of information on social media, the public is free to move and to speak based on what they believe in order to be uploaded on social media and make it as a reference by forgetting the mainstream media as a source of information, thus; some of these indicators lead to the phenomenon of hyperdemocracy [14].
Based on the background outlined above, this study tries to find out the phenomenon of hyperdemocracy in virtual space based on several indicators including the abundance of information coming from social media and is used as a single reference information, in the context of memes on social media instagram which are able to lead the mass to engage in discussions in the comment section to debate, insult, and ridicule among responders.

Covid 19 memes and comment section on social media instagram are used as data in this research, considering that covid 19 is an outbreak which triggers controversy, full of pros and cons to its emergence and handling. In addition, the social media instagram account was chosen in consideration of its consistency in uploading Covid 19 memes from the beginning of the pandemic to the present time. Creators construct information about government policies in handling the outbreak. There are assumptions made by creators about the policy implemented does not benefit the people, but benefit certain groups instead.

Various responses from netizens in the comment section could develop the discussion and even expand on the topic of discussion. Covid 19 has become a global issue and its emergence has provoked a debate, although it has been a year and millions of Indonesians are confirmed to have Covid 19, there are many who still believe it a conspiracy [15]. Some studies show Covid 19 has become a global issue, and a large number of researches are conducted on the virus [16], [17], [18], [19], [20].

\section{LITERATURE REVIEW}

In recent years, memes have conveyed a lot of weariness, anxiety, and dissatisfaction with certain thing. The study of memes has also been conducted from various points of view, including politics, social, cultural, and communication [21],[22], [23], [24], [25], [26], [27], [28], [29], [30], [31], [32], [33], [34].

The focus of this research is to find linguistic evidence as an indicator of the progress of hyperdemocracy in virtual space. In this study, the analysis of interaction processes uses Peirce's semiotic theory developed through semiotic getok tular word of mouth by [35];[36] as well as the analysis of signs and meanings as symbols of a social phenomenon. While non verbal signs are analyzed by using multimodal theory of [37], to find out the process of interaction and relations between memes and comment section on social media instagram, the author uses computer mediated discourse analysis (CMDA) approach by [38]. The author uses the concept of hyperdemocracy by [14], which defines hyperdemocracy as a condition when the masses act because they read the news on social media 
and when the basis of democracy is determined by the number of masses involved and is no longer based on the truth, especially in virtual space through internet uploads that can affect the masses. The danger of the internet is that it threatens and overwhelms us with so much information - too much information - thus giving the impression of democratization and enriching our political lives, while the truth is drowning us in irrelevance [39] and [40].

\section{METHOD}

\subsection{Research Design}

Qualitative approach is used in this study; the approach refers to an emphasis on processes and meanings that are not completely tested or measured in terms of quantity, intensity, frequency, or quantity [40]. In addition, qualitative research was conducted to understand the situations in their uniqueness as part of context and interaction [41]. Based on the definitions, it can be concluded that qualitative research will include data in the form of statements, not in the form of numbers. Moreover, this study also uses pragmatic semiotic design in the context of the signs and its uses are not seen as a structure but rather a cognitive process which is later referred to as semiosis.

\begin{tabular}{|c|c|c|}
\hline $\begin{array}{c}\text { Data Covid } \\
19 \text { Memes }\end{array}$ & Caption & $\begin{array}{l}\text { Number } \\
\text { of } \\
\text { responses }\end{array}$ \\
\hline $\begin{array}{l}\text { Data } 14 \\
29 / 3 / 2020\end{array}$ & $\begin{array}{l}\text { "mudah-mudahan kabar ada yang memanfaatkan menggesa ditengah } \\
\text { penanganan wabah corona itu salah. semoga" (Hopefully, the news of someone } \\
\text { taking advantage amidst the handling of the corona outbreak is wrong. Hopefully.) }\end{array}$ & 11 \\
\hline $\begin{array}{l}\text { Data } 31 \\
18 / 7 / 2020\end{array}$ & $\begin{array}{l}\text { Sampai sekarang sepertinya Pak menterinya belum nemu formula; kecuali sesuai } \\
\text { aplikasi" (It's about the concept of virtual learning for children. School in the } \\
\text { middle of pandemic. Until now, it seems that the minister has not found a } \\
\text { formula, except that should be based on the application.) }\end{array}$ & 31 \\
\hline $\begin{array}{l}\text { Data } 5 \\
15 / 3 / 2020\end{array}$ & $\begin{array}{l}\text { semua rakyat, akan didukung" (whatever good decisions made by government, } \\
\text { transparent, and become idol of all the people, it will be supported). }\end{array}$ & 13 \\
\hline
\end{tabular}

The three memes presented in the table above were uploaded on social media instagram during the covid 19 pandemic. Data 14, based on the meme caption, it implies that there are indications of people taking advantage of this pandemic, data 31 implies uncertainty in the education system during pandemic

\subsection{Data Collection and Analysis}

The data of this study uses the case of netizen responses to covid 19 memes uploaded on social media instagram from the beginning of the pandemic in 2020 to present time. Covid 19 memes are results of the construction of information from meme creators about government measures in handling covid 19 pandemic that the creators assume government does not appear to be serious of the situation. The author found 30 memes uploaded on social media instagram within the time span of the spread of covid 19 outbreak in Indonesia.

Next, the data were analyzed using pragmatic semiotic design. The design was chosen to explore and show the process of discourse on the memes uploaded on social media instagram that informs about Indonesian government's measures in handling covid 19 as an indicator of the emergence of hyperdemocracy phenomenon. After that, the data were interpreted based on netizen responses in the comment section to covid 19 meme uploads.

There are 30 memes collected from social media instagram, starting from the beginning of the pandemic in early 2020 to present time. However, only 3 memes will be presented as data representations in this study: 


\section{DISCUSSION}

In the case of responses in the instagram comment section to covid 19 memes, it shows that there is interaction between the media and responders, meme creators and responders, as well as between fellow responders. Netizens' responses to memes on social media are various. Both meme creators and responders tend to use their own experience and knowledge; it seems that no references are made when constructing and responding to covid 19 memes. Similarly, memes and comment section are based on individual experiences and knowledge, so the objectivity can not be maintained. Therefore, there is a possibility that each responder thinks that he/she is right and considers those with different responses wrong, it leads to a debate and ridicule of each other, is this the real freedom in democracy?

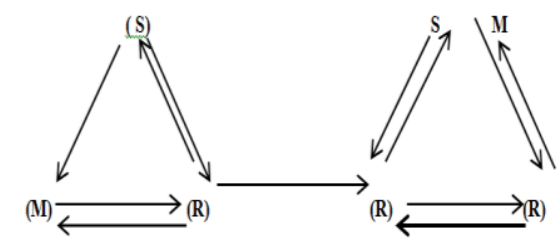

Figure 1: The process of discourse in the meme uploads and comments section on social media instagran

Figure 1 depicts the interactions built between media (M), sources of information (S), and responders $(\mathrm{R})$. Interactions between $(\mathrm{M})$ and $(\mathrm{R})$ is a dialogue but only in one stage, when the media conveys information and is responded by responders, then the media does not respond. Next, interactions between $(\mathrm{S})$ and $(\mathrm{R})$ involve a dialogue and may occur in several stages, and the same thing can be seen in the interaction between (R) and $(\mathrm{R})$, which even leads to intense debate using rude emojis.

Data 14: a meme

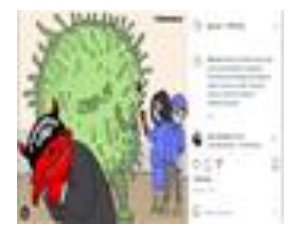
"mudah-mudahan kabar ada yang memanfaatkan menggesa ditengah penanganan wabah corona itu salah. semoga". (hopefully, the news of someone taking advantage amidst the handling of the corona outbreak is wrong. hopefully.)

The meme was uploaded on March 23, 2020 a few months passed since the beginning of pandemic, there was a trending topic about the ratification of omnibus law, and there was an assumption that covid 19 was only part of manipulation done by a group of people. There are four people in this picture: two men and a woman wearing a blue shirt and carrying a microphone, were interviewing a tall round figure, green, inscribed with covid 19, and the last is human but has horns, red skin, wearing black suit, smiling broadly while directing her gaze at the two figures behind her. The figure in a black suit, horned, red-faced, and inscribed with omnibuslaw stared at the other 3 participants with a satisfied smile as if they had achieved victory over a tall, green round figure, inscribed with covid 19. Vector analysis in the image is seen through gazing, as if it was moving from a black suit to 3 figures behind him. Thus, the figure in the black suit becomes reactor while the other 3 figures become a phenomenon; someone whose activities are being told. In (Kress, G., \&Van Leeuwen, 2006), when a vector is formed through the eyes by one of the "participants" so that they see something, then the process is seen as a "reaction" and the participant as a "reactor".

The gaze of the four participants is not directed at us, as readers, but at other directions, so there is no contact from them on us as readers (viewers). When there is no eye contact between represented participant and viewer, then viewer's position is as observer. This gives the observer the opportunity to observe what is happening in the image.

The black color of the suit worn by the represented participant is usually intended to draw a mysterious figure, plus the use of horns on the head, and red on the face illustrates an evil, a cheat. The green color on the round image with various protrusions very clearly leads to the type of virus that is currently spreading, namely covid 19 . The blue color used on the shirts of two figures carrying microphones illustrates tranquility, in the picture the two figures ask or interview a green round figure, trying to seek for more information.

Verbal analysis through the word "omnibuslaw" on a black suit figure, horned, as a relational process and "covid 19" on a green round figure. In the meme, it shows that there is a connection between omnibuslaw and covid 19, omnibuslaw identifies a condition in one place, and in this case, covid 19 is the actor that is spreading rapidly on earth, but there is an omnibuslaw hiding behind the actor, so that the one being hunted is covid 19. Here's how the netizens responded to the meme in the comments section:

1) S\&M: mudah-mudahan kabar ada yang memanfaatkan menggesa ditengah penanganan wabah corona itu salah. Semoga (Hopefully, the news of someone taking advantage amidst the handling of the corona outbreak is wrong. Hopefully.)

2) R1 : Diam2 menghanyutkan... Presidennya juga diem aja (The president keeps silent.) 
3) R2: $\quad$ Rakyat disuruh dirumah aja, sepakat itu buat menghentikan penyebaran virus, tapi kan rakyat butuh makan, blom lagi dengan entengnya ngomong, orang miskin jangan nularin ke orang kaya, berasa mau ngerobek mulutnya.(People are told to stay home, I agree it would stop the spread of the virus, but people need to eat, and he said that the poor do not transmit the virus to the rich, I feel like ripping his mouth.)

4) R3: Omnibus law, Harun masiku, jiwa seraya dan masih banyak lain ngambang kaya (Omnibus law, Harun masiku, Jiwa Seraya and many other issues

5) R4: Semoga yang memanfaatkan keadaan malah terkena COVID9 ga bisa sembuh! (Hopefully those who take advantage of the situation even get infected by COVID9 and can not recover!)

The utterance 1) is a meme caption written by a source of information on social media instagram along with the upload of meme, while utterance 2), 3), 4), and 5 ) is a response showing support to the upload of covid 19 meme constructed by creators as a representation of the issue that covid 19 is only a manipulation from business groups and the government. Utterance 3) appears to use an emoji resembling feces and cats to show anger at the government for some obscure cases, which is illustrated like "cat feces". All responses seem to agree and believe that the information constructed in the meme as a truth, it is confirmed through the caption written by the creator "Hopefully, the news of someone taking advantage amidst the handling of the corona outbreak is wrong. Hopefully."

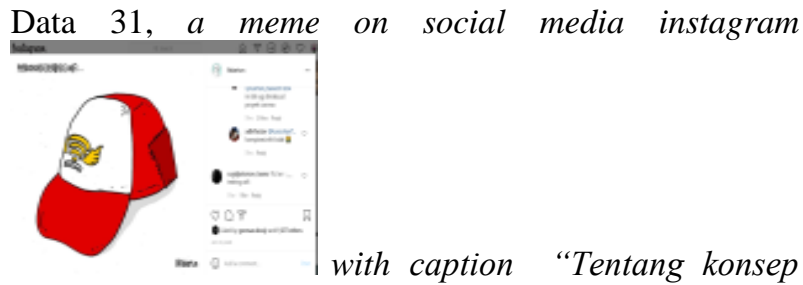

belajar virtual anak-anak. Sekolah ditengah pandemi. Sampai sekarang sepertinya Pak menterinya belum nemu formula; kecuali sesuai aplikasi" (It's about the concept of virtual learning for children. School in the middle of pandemic. Until now, it seems that the minister has not found a formula, except that should be based on the application.)

Reactional Process, a meme on data 31, was uploaded on July 18,2020 to coincide with the start of the new school year amidst the pandemic with positive cases were still quite high. According to (Kress, G., $\&$ Van Leeuwen, 2006) in the reactional process, a picture of the position of the represented participants is usually displayed. Participants are objects displayed in the picture, which may consist of living objects and inanimate objects.

Reactor, in this meme is shown through an object resembling a hat used by elementary school student, with a symbol resembling an image of the internet network (wifi), and on the right side of the hat there is a patch which is usually used to cover a torn cloth. On the left corner, "wifi-based education" was written; the hat looks dull with a patch on it, with the caption "It's about the concept of virtual learning for children. School in the middle of pandemic. Until now, it seems that the minister has not found a formula, except that should be based on the application".

Overall, the meme seems to describe the current condition of education in the middle of covid 19 pandemic which is conducted online. Online learning is not necessarily able to be followed by all students in all regions because of the limited internet access and the expensive cost of having a device as a digital learning tool. The responders assume that the current direction of education is unclear and this situation is considered as one of the corona projects. Here's how the netizens responded to the meme in the comments section:

1) S\&M : Tentang konsep belajar virtual anak-anak. Sekolah ditengah pandemi. Sampai sekarang sepertinya Pak menterinya belum neтu formula; kecuali sesuai aplikasi. (It's about the concept of virtual learning for children. School in the middle of pandemic. Until now, it seems that the minister has not found a formula, except that should be based on the application.)

2) R1 : Sesuai titik ya bang Sesuai titik ya bang (According to the pick-up point, bang.)

3) $R 2$ : $\quad$ kayak semua anak punya komputer + internet aja (As if all children had computer and internet)

4) $R 3$ : Tut Wi-Fi Handayani (Tut Wi-Fi Handayani)

5) R4 : Aplikasi Ruang guru dan indihome naik drastis wkwkwkwwk (The application of Ruang Guru and Indihome will rise dramatically wkwkwkwwk)

6) R5 : $\quad$ Tut wuri tetring wifi (Tut wuri tetring wifi)

7) R6 : Mungkin ini juga ada benernya tentang penghapusan honorer atau mungkin pengurangan PNS (Maybe this is something about the removal of honorary workers or maybe the reduction in the number of civil servants.) 
8) R7 : mnding mentrinya balik lg dah di gojek...bkin rusuh doang jdi mentrißિ) (Maybe it's better for the minister to lead the company again, gojek, not becoming a minister ... only causing a chaos 今िज्ञ

9) R8 : Kasih dong internet gratis selama anak sekolah belajar dirumah.....(Give free internet quota to children for online learning .....)

10) R9 : Sesuai aplikasi ya kak (According to the application, ya kak (:))

11) R10 : Tut wuri handawifi (Tut wuri handawifi)

12) R11 : Lebih tepatnya pendidikan berbasis Online Min@fakartun @ (More precisely to say, it's online-based education, Min @ fakartun (:)(:)(:)

13) R12 : Kalo saya jadi mentri. Kalo nih. Mending pelajaran silabusnya di bikin virtual. Pelajaran lewat vidio. Contoh. Youtube ( pinter politik) menurut saya seru belajar politiknya. Nah kesekolah di jadwal. Cuma buat ulangan doang.. (If I were the minister... Only if.. I think it's better if the lesson syllabus is made virtually. Lessons through video. For instance, Youtube. I think it's fun to learn politics. We'll go to school based on the schedule. Just for taking the test. (0))

14) R13 : Solusinya bagaimana dong $\square$ @fakartun (So, what is the solution? $\square$ @ fakartun)

15) R14 : nunggu solusi dari pak menteri (Waiting for the solution from the minister is)

16) R15 : Ga takut ninu ninu (Not afraid, ninu ninu 今)

The utterance 1) is a caption for meme written by the source of information (meme creators) on social media instagram along with the upload of meme, while the utterance 2), 3), 4), 5), 6), 7), 8), 9), 10), 11), 12), $13), 14)$, and 15) are responses from responders in the comments section. Speech 13) is a response that is directly intended for the source of information (meme creators) and there is a dialogue between the two as it is directly responded by the source of information (meme creators) in the utterance R14. Responses 1), 2), 3), 4), 5), 6), 7), 8), 9), 10), 12), and 15) are responses which show support for what creator has constructed the information about the condition of education implemented online during this pandemic which is hard for some people to implement. To be able to follow distance learning, children must have gadgets and internet packages in order to access it. Netizen responses were trying to interpret what is shown in the meme about current education in Indonesia that enforces online learning. This is done with the aim of breaking the chain of covid 19 spread. However, many responses show that there are assumptions of incompetence of the minister of education in preparing the learning model during this pandemic.

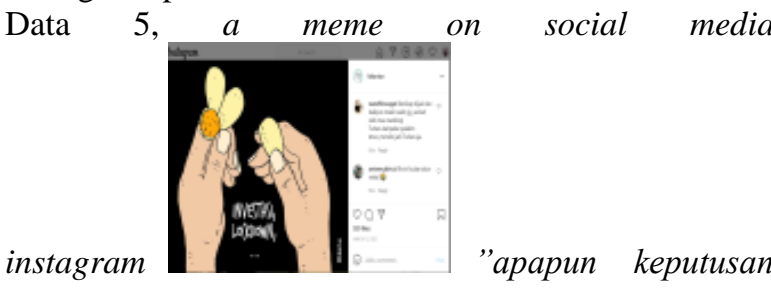
pemerintah yang baik, serba transparan dan idola semua rakyat, akan didukung" (whatever good decisions made by government, transparent, and become idol of all the people, it will be supported).

Reactional Process, a meme on data 5, was uploaded on March 15, 2020 to coincide with the beginning of the announcement of covid 19 spread in Indonesia. The government had planned a lockdown or quarantine for some regions to break the chain of covid 19 spread. According to (Kress, G., \&Van Leeuwen, 2006) in the reactional process, a picture of the position of the represented participants is usually displayed. Participants are objects displayed in the picture, which may consist of living objects and inanimate objects. Reactor in this meme is shown through a hand-like object complete with fingers that are seen picking yellow flowers one by one. In addition, "investment lockdown" was written in the middle of both hands. With caption " whatever good decisions made by government, transparent, and become idol of all the people, will be supported ", implying there are government policies which are not in accordance with the condition in the midst of the covid 19 pandemic.

Overall, the meme seems to describe the situation, especially the economy in the midst of covid 19 pandemic. Government experienced confusion when dealing with the handling of pandemic, whether to let investment continue to improve the economy or to impose lockdown to save the society from covid 19 pandemic. Responders have the same assumptions as the creator regarding government policy that it turns out the government prefers to keep investing to save the economy in this pandemic situation. Here's how the netizens responded to the meme in the comments section:

1) $\mathrm{S}$ and $\mathrm{M}$ : apapun keputusan pemerintah yang baik, serba transparan dan idola semua rakyat, akan didukung (whatever good decisions made by government, 
transparent, and become idol of all the people, it will be supported)

2)R1: $\quad$ Yang transparan malah dinyinyirin hmm ngetizen maha benar ya om (The transparent ones will get negative comments, hmm... netizens are always right, ya Om)

3)R2:

4)R3:

5)R4:

6)R5:

7)R6:

8)R7 :

9) R8 :

11) R10 :

लिडिड्ड

Pemerintah masih mentingin ekonomi, rakyat mah di belakanhigin. \#miris (The government still prioritizes in the economy, the people are not the first priority .\#sad)

bertahan demi cuan $\mathcal{E}$ (To survive, for the sake of money $\boldsymbol{\Xi}$

Serba salah yaa...pokoknya mau gimana jg salah (It's all wrong... the point is.. everything is wrong.)

Gak ada guananya pengusaha investasi kalo konsumennya pada dirumah sakit (There is no point of investing your money if the consumers are in the hospital)

Skrg dollar udh 14 rbu lbih. Klo lockdown kemungkinan bs 15 rbu. Klo udh 15 rbu ntr perekenomian terganggu. $\mathrm{Yg}$ disalahin pemerintah $\mathrm{lg}$. Susah ya jdi pemerintah. Serba salah. Gk bs menyenangkan smua pihak :v (Now, 1 dollar is Rp.14,000. If government impose lockdown, it may reach Rp.15,000. If it reaches Rp.15,000, the government will be blamed again. It's not easy for the government. It can not please everyone :v)

Iya betulll...apapun yang terjadi salahnya tetap pemerintah pusat. (Yes, right... Whatever happens, the central government is always wrong.)

10) R9 : Izin repost (I'm asking for permission to repost it. îi)

Dari 575 anggota DPR, 262 mendukung omnibuslaw karena 45,5\% anggota DPR adalah pengusahan, yaaaa anggep aja ini adalah perselingkuhan penguasa dan pengusaha.. (Of the 575 members of the House of Representatives, 262 support omnibuslaw because $45.5 \%$ of members of the House of Representatives are businessmen, well.. this is like having an affair between officials and businessmen.)
12) R11 : $G g$ akan mungkin diidolain semua rakyat. Udah di nash kok. Mesti ada yang kontra (You won't be idolized by all the people. There must be some cons.)

13) R12: $\quad$ Bersikap bijak dan baikpun masih salah jg,,,seolah olah mau nandingi Tuhan..daripada nyalahin terus,,mendin jadi Tuhan aja.. (Be wise and good is still wrong, it's like you want to challenge God.. don't keep blaming..)

14) R13 : fix ini bukan akun netral 0 (It's fixed, this is not a neutral account (2))

The utterance 1) is a caption written by a source of information (meme creator) on social media instagram along with the upload of meme, while the utterance 2, 3), 4), 5), 6), 7), 8), 9), 10), 11), 12), 13), and 14) are responses from responders in the comments section. The utterance 2), 6), 8), 9), and 13) are direct responses aimed at the source of information (meme creator) and other responders who have the same way of thinking as the creator. Responses 4), 5), $7), 11), 12$ ), and 14) are responses which show denial to the information constructed by creator about the government's measures in dealing with the pandemic; the government must choose between lockdown or investment. Netizen responses were trying to interpret what was shown in the meme about the government's measures in dealing with the pandemic. However, many responses show that there are assumptions of confusion from the government to keep letting investors continue to invest or to impose lockdown in order to break the chain of covid 19 spread.

The new public space increasingly shows the proliferation of democratization in virtual space as in previous studies conducted by (Dharmawan, 2015), (Jati, 2016), and (Fatah, 2019). In addition, democratization in virtual space has also become findings in a research conducted by (Hoed, 2011), and (Saifullah, 2014), both found the process of democratization, but in different structures namely "Top down" to "dialogue" and "Top down" to "Bottom up" in the cyber news media. The positive thing is when the abundance of information is increasingly unstoppable, it becomes a part of democratization of information in which its existence cannot be denied. However, to understand the information, choosing the one that can be trusted must be done wisely and thoroughly.

Anonymous accounts used in the internet uploads and in responses appear to show the development of democratic for participants in giving opinions and expressing themselves in a virtual space, 
but it does not necessarily guarantee the quality of democracy formed. The abundance of information sometimes triggers disunity because it tends to be responded with negative emotions, harsh words, and the use of emojis that should not be directed at other netizens.

Today, what is currently happening in society is that each individual is free to convey any information that he/she believes to be true. Everyone seem to justify this, so it causes information overload in public spaces and confuse the public to choose which information is true and trustworthy. Some of the above phenomena, can be used as an indicator of the progress of hyperdemocracy, where the public believes more in the news or information circulating on social media, in this case it is a meme that has a level far from the news in conventional media and mainstream media. Each individual is free to participate in public spaces, debating with each other without referring to the correct source of information. In the context of this study, memes constructed by creators have been used as sources of information or references and are able to influence netizens to act and argue which even leads to a debate. Thus, it can be concluded that social media has dominated the public, although the response is still dominated by the public.

Based on the context above, interactions that occur on social media instagram are based on media context factors [38], which include: the response is asynchronous which means that anyone can be involved in, each responder is free to deal with the response, whether it will be saved or read immediately and responded to. Transmission of messages, which means if the responder wants to direct his response to another source of information or responders, it can be uploaded anytime and anywhere, without having to wait for other responders and the source of information to be active or on.

The characteristic of messages is that it can last long enough and is free to be responded by anyone, the size is not limited, information channels can use texts, images, and emojis, anonymous messages or the same accounts are widely found in these interactions, responses are dominated by private messages, and are based solely on individual experience and knowledge, therefore; the characteristic of messages or responses is highly subjective. In the context of media, particularly social media, there is no supervision for any uploads so that the responses or messages uploaded may contain a lot of harsh words including insult, ridicule, criticism which is not based on reliable sources. Quotations, in the context of this study, some responses mention or refer to a particular person with no intention to quote his/her statement, but rather to corner or insinuate the person. Next, the format of incoming messages is based on the order of time (date, month, year) when the response is received.

The next factor is the context of the communication situation; the structure of participant shows some of the responses are dominated by anonymous accounts, anyone can engage in such discussions. The characteristics of the participants, which tend to vary and are reflected through the dictions used in the responses. Next is the purpose, which is to respond to the memes uploaded on social media instagram that is constructed by the source of information (meme creator). Information constructed in memes is merely an individual judgement of the meme creator as a source of information, besides; there is also an expansion on the topic of conversation / discussion in the forum. Themes or topics, information and opinions related to social and political issues aimed at the government, related to the policy of handling covid 19.

The tone used is various, some are conveyed with rude, emotional, humorous, even provocative tone. Activities, in this category, contain responses to respond to meme uploads and their captions, to argue or ridicule among responders or even from responders directed to the source of information (meme creator). While norms fit into the informal category and tend to insult, criticize, and exaggerate issues especially related to government policies in handling the covid 19 pandemic. Finally, the utterances used fit into the casual category, colloquial language, and a large number of spoken languages written.

The results of the analysis of verbal and nonverbal signs in memes show that the intent constructed by the source of information (meme creator) is based on the creator's understanding and truth about the alleged conspiracy behind the covid 19 outbreak.This is understood by the commentators in the comments column as an act of government, regime, and small groups in power so as to move the conspiracy. This understanding has received a lot of support from responders and is believed to be a truth without any source of comparative information. But there are some responders who argue against the information constructed in memes and tend to side with the government in this regard as a publicly cornered party.

The results of the analysis of verbal and nonverbal signs in memes show that the intention constructed by the source of information (meme creator) is based on the creator's judgement and justification about the alleged conspiracy behind the covid 19 outbreak. For instance, the ratification of omnibuslaw, that covid 19 was deliberately raised to facilitate the ratification of the omnibuslaw, distance 
learning during the pandemic is considered as the uncertainty of the current direction of education, and netizens also believe there are assumptions that the government would rather keep investment opportunities going than impose a lockdown to break the chain of covid 19 spread. This is understood by the responders in the comments section as an act of government, regime, and powerful groups to attempt the conspiracy. It has received a lot of support from responders and is believed to be the truth, even without any source of comparative information. However, there are some responders who are against the information constructed in memes and tend to support the government which is cornered by public.

Based on the results of the analysis, the interactions take place in virtual space through the upload of covid 19 memes. Interactions occur between responders and media is when social media displays memes, but interactions only occur in one stage. Next, interactions also occur between sources of information (meme creator) and responders which include several stages. Similarly, the interaction between fellow responders, also take place in several stages which lead to a debate, insult, ridicule, and discredit one of the responders. All information constructed by creator through meme uploads and responses in the comments section is based on individual thoughts, knowledge and experiences. There are various emojis used in some responses that show the outpouring of feelings of each responder. It is clearly seen that individual's beliefs and judgements are capable of influencing the masses to act and are believed to be the truth.

\section{CONCLUSION}

Research findings show Covid 19 memes and its comments are brutal and anarchy. Most of the comments are insulting, cussing, and discrediting particular parties. Those phenomenon can be considered as hyperdemocracy. Furthermore, the advancement of technology and internet make people can easily receive and share information anytime and anywhere. Therefore, it makes people are confused to choose trusted sources. Now days, memes plays important role as one of the information sources which trusted by most of the people. Whereas, some memes only creation of creators which sometime are subjective. When it happened more and more hyperdemocracy will appear. This research can be concluded that virtual space as a discussion forum where people can involve. By this easiness of receiving and sharing information makes it uncontrolled. People are arguing to defend their argument subjectively and brutally. If it happens continuously, Indonesian citizen can be disunity. To investigate further finding, in-depth research should be conducted.

\section{REFERENCES}

[1]D. McQuail, Teori Komunikasi Massa (Terj.). Jakarta: Salemba Humanika, 2012.

[2]N. Hasfi, S. Usmand, and H. P. Santoso, "Anonimitas di Media Sosial: Sarana Kebebasan Berekspresi atau Patologi Demokrasi?," J. Ilmu Komun., vol. 15, no. 1, pp. 28-38, 2017.

[3]A. R. Saifullah, "Pengembangan Model Analisis Relasi Bahasa Dan Internet Berbasis Paradigma Cmda (Computer Mediated Discourse Analysis)," J. Pendidik. Bhs. dan Sastra, vol. 17, no. 2, p. 169 2017.

[4]P. S. Perbawani, R. Rahayu, and I. N. Anshari, "Online Political Participation and Netizen Anonymity in Indonesia's Digital Democracy," PCD J., vol. 6, no. 2, p. 185, 2018.

[5]H. Asenbaum, "Anonymity and democracy: Absence as presence in the public sphere," Am. Polit. Sci. Rev., vol. 112, no. 3, pp. 459-472, 2018.

[6]C. Forceville and B. Clark, "Can Pictures Have Explicatures?," Ling. em (Dis)curso, vol. 14, no. 3, pp. 451-472, 2014.

[7]S. Ayvaz and M. O. Shiha, "The Effects of Emoji in Sentiment Analysis," Int. J. Comput. Electr. Eng., vol. 9, no. 1, pp. 360-369, 2017.

[8]B. Arafah and M. Hasyim, "Linguistic functions of emoji in social media communication," Opcion, vol. 35, no. 24, pp. 558-574, 2019.

[9]S. Gupta, A. Singh, and J. Ranjan, "Sentiment analysis: Usage of text and emoji for expressing sentiments," in Proceedings of ICDIS, 2019, vol. 94, pp. 477-486.

[10]A. Sampietro, "Emoji and rapport management in Spanish WhatsApp chats," J. Pragmat., vol. 143, pp. 109-120, 2019.

[11]R. Dawkins, Selfish gene, Anniversar., vol. 214, no. 2865. New York: Oxfor University Press, 2006.

[12]L. Shifman, "Humor in the age of digital reproduction: Continuity and change in internet based comic texts,” Int. J. Commun. 1, p. 204, 2007.

[13]L. Shifman, "Memes in a digital world: Reconciling with a conceptual troublemaker," J. Comput. Commun., vol. 18, no. 3, pp. 362-377, 2013.

[14]S. Welch, Hyperdemocracy, First Edit. Palgrave Macmillan, 2013.

[15]Kompas, "Melangkah di Tangah Labirin Informasi," Kompas, Jakarta, p. 15, 2021.

[16]F. Yang et al., "Analysis of the global situation of COVID-19 research based on bibliometrics," Heal. Inf. Sci. Syst., vol. 8, no. 1, pp. 1-10, 2020.

[17]H. Harapan et al., "Coronavirus disease 2019 
(COVID-19): A literature review," J. Infect. Public Health, vol. 13, no. 5, pp. 667-673, 2020.

[18]T. Ibn-mohammed, K. B. Mustapha, J. Godsell, Z. Adamu, K. A. Babatunde, and D. D. Akintade, "A critical analysis of the impacts of COVID-19 on the global economy and ecosystems and opportunities for circular economy strategies," Resour. Conserv. Recycl., vol. 164, no. January, pp. 1-22, 2020.

[19]K. Syuhada, A. Wibisono, A. Hakim, and F. Addini, "Covid-19 risk data during lockdown-like policy in Indonesia," Data Br., vol. 35, pp. 1-9, 2021.

[20]N. Kvirkvelia and M. Tsitsagi, "Impact of Covid 19 on -19 on Tourism in Georgina-an Overview," Georg. Geogr. J., vol. 1, no. 1, pp. 27-33, 2021.

[21]C. Wallis, "New media practices in China: Youth patterns, processes, and politics," Int. J. Commun. 1, vol. 5, pp. 406-436, 2011.

[22]S. Du, "Social media and the transformation of 'Chinese nationalism': 'Igniting positive energy' in China since the 2012 London Olympics," Anthropol. Today, pp. 5-8, 2014.

[23]A. Denisova, "Online memes as a means of the carnivalesque resistance," in the symposium Politics and Humour Theory and Practice, Kent, UK, 2014.

[24]S. C. Sudarsono, "Representasi masyarakat Indonesia yang tecermin melalui ketidakjujuran dalam wacana humor meme awas itu hoax," 2017 , pp. 21-25.

[25]R. R. Pusanti, "Representasi Kritik Dalam Bentuk Meme Politik," J. Komun. Massa, vol. 1, pp. 1-19, 2015.

[26]B. E. Wiggins, "Crimea river: Directionality in memes from the Russia-Ukraine conflict," Int. J. Commun., vol. 10, pp. 451-495, 2016.

[27]C. Judhita, "Meme di Media Sosial: Analisis Semiotik Meme Haji Lulung," Pekommas, vol. 18, no. 2, pp. 105-116, 2015.

[28]I. A. Arestova, A. Y., Balandina, E. V., \& Budko, "The etymology of "Internet memes," in the Student Science Forum 2015, Moscow, Russian Federation, 2015.

[29]W. E. Nuryaningsih, "Wacana Humor dalam Akun 'Dagelan' diInstagram," Uiversitas Gdjah Mada, 2015.

[30]S. Cannizzaro, "Internet memes as internet signs: A semiotic view of digital culture," Sign Syst. Stud., vol. 44, no. 4, pp. 562-586, 2016.

[31]K. El, "Living in Darkness: Internet Humor and The Politics Egypt's Electricity Infrastructure," Antropol. Today, pp. 21-24, 2016.

[32]A. Osterroth, "Semiotics of Internet Memes," no. 2009, 2018.

[33]R. S. Dewi, "Kreator Meme dan Konstruksi Makna Meme Politik di Media Soaial," J. Komun. Glob., vol. 8, no. 1, pp. 1-16, 2019.

[34]S. Handayani, E., Chasana, S., Mahmudah, N., Assidik, GK., \& Waljinah, "Representasi Kehidupan Dalam Program Meme di Instagram: Analisis Wacana Kritis Model," in The 10th University Research Colloqium 2019 Sekolah Tinggi Ilmu Kesehatan Muhammadiyah Gombong, 2019, pp. 180-184.

[35]H. B. Hoed, Semiotik dan Dinamika Sosial Budaya, Kedua. Depok: Komunitas Bambu, 2011.

[36]H. B. Hoed, Semiotik dan Dinamika Sosial Budaya. Depok: Komunitas Bambu, 2014

[37]T. Kress, G., \& Van Leeuwen, Reading Images. New York: Routledge, 2006.

[38]S. C. Herring, A Faceted Classificaton Scheme For Computer-Mediated Discourse. Bloomington: Indiana University Press, 2011.

[39]B. S. Noveck, Paradoxical Partners: Electronic Communication and Electronic Democracy," in The Internet, Democracy, and Democratization, Peter Ferd. London and Portland, OR: Frank Cass, 2000.

[40]M. Castells, Networks of Outrage and Hope: Social Movements in the Internet Age. Cambridge and Malden, MA: Polity Press, 2012.

[41]M. Q. Patton, Qualitative Research and Evaluation Methods. USA: Sage Publications inc, 2002. 